\title{
I. LIBERALISM AND THE JEWISH CONNECTION
}

\section{A Study of Spinoza and the Young Marx}

\author{
JOEL SCHWARTZ \\ University of Michigan
}

N THIS ARTICLE I will discuss a sensitive and potentially controversial subject - the criticisms of Judaism to be found within the works of two notable political philosophers of Jewish ancestry, Spinoza and the young Marx. ${ }^{1}$ In assessing the thought of these important figures, contemporary readers generally ignore their critiques of Judaism: They assume that these critiques are irrelevant to the thinkers' serious political and philosophical concerns, and that the critiques might at most be of psychological interest, enabling us better to understand the thinkers as "self-hating Jews."

But these assumptions are, I believe, invalid. Instead, a serious examination of Spinoza's and the young Marx's respective attitudes toward Judaism can be of great assistance in facilitating a proper assessment of their political and philosophical positions. Specifically, such an examination is useful in elucidating the reasons behind Spinoza's advocacy of liberalism and the young Marx's rejection of it. Spinoza's and the young Marx's critiques of Judaism may well be of no great theological significance; because they are relevant to the philosophers' respective assessments of liberalism, they are nevertheless of great political significance. This is because Judaism functioned for both authors as a metaphor for liberalism. Whatever their other disputes, Spinoza and the young Marx both agreed that liberalism resembles Judaism in the following crucial respects: Both Judaism and liberalism, they thought, are concerned only with men's actions, not with their 
opinions; both Judaism and liberalism, they thought, promote legalistic and materialistic recognition of individual self-interest.

Spinoza was the first thinker to employ the metaphor linking Judaism to liberalism. Although Spinoza was an apostate Jew, who rejected Judaism upon perceiving what he took to be its deficiencies, he saw strengths as well as weaknesses in the Jewish conception of the world. Spinoza believed that both Judaism's strengths and weaknesses were also to be found in the liberal conception of the world. Spinoza therefore advocated liberalism because of the strengths that he believed it to share with Judaism, and in spite of the weaknesses that he believed it to share with Judaism.

Spinoza pointed to the affinities between Judaism and liberalism in his discussion in the Theologico-Political Treatise of the Biblical commonwealth founded by Moses. If the liberal state is understood as a state that controls some of our actions but (in principle) none of our opinions, Spinoza can be said to have portrayed this commonwealth in decisive respects as the protoliberal state.

In saying this, I do not mean to suggest that Spinoza believed that liberalism was either conceivable or defensible only because of Biblical precedent in its favor. Spinoza was instead a liberal because of his acceptance of a secular teaching about natural rights. Nevertheless, the precedent of the Jewish commonwealth was important to him for two reasons. First, it provided empirical evidence that a political community could maintain itself successfully while restricting its control to its subjects' actions alone. Second, the fact that his example of the successful commonwealth was drawn from the Bible (and not from pagan antiquity) was also important in that Spinoza wanted to make liberalism acceptable to others who would reject secular teachings in favor of Biblical teachings. In order to persuade such potential converts to liberalism, he found it rhetorically useful to emphasize the Biblical roots of his political and philosophical position. ${ }^{2}$

Thus it was rhetorically convenient for Spinoza to profess admiration for the political arrangements of the Biblical Jewish commonwealth. Nevertheless, his admiration was genuine (even though, we shall see, he by no means believed that the Biblical commonwealth was unqualifiedly liberal or unqualifiedly above criticism). The Biblical commonwealth conformed only partially to the model of the liberal state. This partial resemblance between the Jewish state and the liberal state points, however, to both the strengths and weaknesses of liberalism.

In Spinoza's view, an important strength of liberalism is manifested in the liberal state's subjection only of actions, never of opinions, to 
governmental control. The liberal state recognizes the impossibility of "preserv[ing] peace, unless individuals abdicate their right of acting entirely on their own judgment. Therefore, the individual justly cedes the right of free action, though not of free reason and judgment." In Spinoza's presentation, the Biblical Jewish commonwealth conformed to this rule, and was therefore a political model worthy of emulation. By contrast, Christianity as portrayed by Spinoza was a fundamentally apolitical religion that failed to understand the importance of "preserv[ing] peace," or the connection between governmental control over actions (and indifference to opinions) and the preservation of peace. Judaism but not Christianity was a model for the liberal state, in that Judaism but not Christianity paid sufficient heed to the exigencies of the public sphere.

But Spinoza held that Judaism's indifference to opinions illuminates not only the strengths of liberalism, but its potential weaknesses as well. To see this, one must pursue the comparison between Judaism and Christianity begun above. For if in Spinoza's view Judaism's indifference to opinions renders it politically superior to Christianity, in another respect it manifests Judaism's inferiority to Christianity. Spinoza portrayed Christianity as a theoretical, opinionated religion, aware of and alive to the greatest good, which is a transpolitical good-"the knowledge of the union existing between the mind and the whole of nature"; Judaism, however, he depicted as an untheoretical religion, indifferent to knowledge as well as to opinion, wholly oblivious of this greatest good. He argued that Christianity but not Judaism paid sufficient heed to the opportunities offered in the private sphere, the sole sphere in which the individual can achieve moral and intellectual perfection.

I do not mean to suggest that Spinoza accurately characterized Judaism and Christianity; many of his characterizations of Judaism in particular are offensive. ${ }^{5}$ I do mean to suggest, however, that his descriptions of the two religions are important though inaccurate. Spinoza was undoubtedly wrong simply to equate Judaism with limited political concerns. The equation is significant, however, in that it indicates the ambivalence of Spinoza's advocacy of the liberal state. If the liberal state, like the Biblical Jewish commonwealth, must be limited in its concerns, and if Spinoza criticized Biblical Judaism as well as praising it for this limitation, which reveals Biblical Judaism's indifference to transpolitical goods, then the liberal state too must deserve criticism as well as praise, in that it is necessarily oblivious to the greatest good, the achievement of moral and intellectual perfection, which in 
Spinoza's view can be attained only on an individual and private basis. By identifying liberal politics with the protection of the peace and the preservation of the body, and by divorcing it from any direct concern with the perfection of mind and morals, Spinoza necessarily deprived public life of much of its possible dignity. ${ }^{6}$

In response to these questions of dignity and perfection, the young Marx introduced his variant of the Judaism-liberalism metaphor. Spinoza's metaphor recurs in the critique of Judaism to which the essay "On the Jewish Question" is in part devoted. The critiques of Judaism and liberalism that appear there are in fact a radicalized rejoinder to Spinoza's earlier critique of Judaism and somewhat ambivalent defense of liberalism.

The son of an apostate Jew, the young Marx enthusiastically seconded his father's rejection of Judaism, upon perceiving what he took to be Judaism's deficiencies. The deficiencies to which the young Marx pointed were identical to those which Spinoza had discussed earlier. Significantly, however, the young Marx differed from Spinoza in seeing only weaknesses in the Jewish conception of the world, without perceiving any corresponding strengths; he argued that Judaism's weaknesses were also to be found in the liberal conception of the world. The young Marx therefore became one of liberalism's greatest critics; in his criticism he employed the equation between Jewish and liberal failings that he discerned.

The analysis of Judaism was clearly of far greater concern to Spinoza, who knew much about Judaism, than it was to the young Marx, who did not. Thus Judaism was a major focus of the only book about politics that Spinoza lived to complete, whereas Judaism was a major focus of only one of the several essays written by the young Marx. This explains the obvious disproportion in the attention that I devote to the two authors in this article. Spinoza's discussion of Judaism could be studied profitably with no attention paid to that of the young Marx; the converse would not, I believe, be true. But if the young Marx's discussion of Judaism is without compelling interest when taken by itself, it is still of considerable interest when considered in conjunction with Spinoza's earlier discussion. The young Marx's critique of Judaism can best be understood as a sort of postscript or abbreviated sequel to Spinoza's more extensive critique. Because the young Marx, like Spinoza, pointed to affinities between Judaism and liberalism, a consideration of the former's analysis of Judaism offers us a useful vantage point from which to consider his attempted abolition and transcendence of the liberal tradition within which Spinoza played so 
important a part. In criticizing Judaism, the young Marx also criticized the liberal assumption, propounded by Spinoza, that communal action can provide us only with limited goods. This is true of liberal politics, the young Marx believed; but he denied that it was necessarily true of all communal action. Unlike Spinoza, the young Marx therefore came to believe that a new, "Christian" understanding of communal action could replace the deficient "Jewish"-liberal understanding. As a liberal, Spinoza had argued that the political and the transcendental were necessarily separate; the young Marx became a communist because he believed that they could be united, that the greatest good could be achieved through communal action. The role played for Spinoza by private philosophical contemplation is fulfilled for the young Marx by public revolutionary action.

\section{THE PLACE OF THE POLITY IN JUDAISM AND CHRISTIANITY}

Spinoza was a liberal in that he believed that in certain respects the power of the state must be limited. As a corollary to this argument, however, he also believed that in other respects its power must be strengthened. The state must be strong enough to control certain of our actions in order to secure the public peace; only then could it limit its power so as to liberate our thought from its control.

Spinoza presented the Biblical Jewish state as a model to his Christian readers because he believed that Judaism understood far better than did Christianity the need for a strong polity and the limits to the control exercised by the polity. "The truth of Judaism"(regrettably not, in Spinoza's view, shared by Christianity) lay in its recognition that "a man in effect can live humanly only in the midst of a politically organized society, and that it is up to the political authority to determine the accord of all sincere fervor with the public interest." The liberal state was to share the Jewish state's recognition of the importance of the polity. It could do so only if it adopted "Jewish" remedies for the deficiencies that had historically plagued the polity in the Christian world: Judaism and not Christianity understood the importance of the polity because Judaism had been created as a means of strengthening a state whereas Christianity had been created in opposition to a state.

This comparative evaluation emerges from one of Spinoza's very important contrasts between Moses and Jesus, the greatest figures in the 
respective religions. ${ }^{8}$ Spinoza attempted to account for the difference between the Old Testament morality of "an eye for an eye" and the New Testament morality mandating that one "turn the other cheek." $\mathrm{He}$ contended that the difference between the two moralities could be explained by the different political circumstances in which Moses and Jesus lived. "Moses (who did not write in times of oppression, butmark this-strove to found a well-ordered commonwealth) ... ordained that an eye should be given for an eye." By contrast, Jesus's "words were spoken to men who were oppressed, who lived in a corrupt commonwealth on the brink of ruin, where justice was utterly neglected.... This precept of Christ ... was only valid in places where justice is neglected, ... but does not hold good in a well-ordered state." Moses' morality is not absolutely superior to Jesus', but unlike Jesus', it is designed to apply to the well-ordered state. Because Spinoza's purpose in writing the Theologico-Political Treatise was precisely to improve the ordering of the state, it is obvious that in this respect he was more sympathetic to Moses' morality than to Jesus'. He shared Moses' concern (how to improve the polity), not Jesus'(how to live well in spite of the corruption of the polity). ${ }^{10}$

Spinoza began his most extended discussion of Moses' rule by noting that "kings ... used to try to spread the idea that they were descended from the immortal gods"11 in order to secure their rule. Spinoza understood Judaism in this perspective; it was introduced by Moses, a political ruler, so as to solidify his rule. Religion was created out of political necessity, and subordinated to political necessity. The Jews' "Church began at the same time as their dominion, and Moses, their absolute ruler, taught religion to the people.... The kings kept a firm hold on their spiritual prerogatives."12 The original purpose of the Jewish religion was to facilitate obedience to the Jewish state. This is precisely the role that Spinoza believed religion should play in all states; only thus could religion promote rather than threaten public peace, security, and comfort. ${ }^{13}$ "Religion acquires its force as law solely from the decrees of the sovereign.... The rites of religion ... should be in accordance with the public peace ... and should therefore be determined by the sovereign power alone." 14

Unlike Judaism, Christianity weakened the state in which it came into being. This is because it was begun by men who were indifferent or even opposed to the political power of their sovereign (i.e., the Roman emperor). "The Christian religion was not taught at first by kings, but by private persons, who, against the wishes of those in power, whose subjects they were, were for a long time accustomed ... on their own 
authority to settle and decide on their affairs without regard to the state." 15

Even when Christianity became an established state religion, it was unable to solve the problems posed by religious opposition to sovereign political authority; in fact, the ecclesiastical authorities did not care to solve the problems, but instead deliberately exacerbated them. In Judaism (in principle if not always in practice), the priesthood was subordinated to the state's rulers. ${ }^{16}$ In Christianity, by contrast, the priests, who had not received their authority from the sovereign attempted to maintain their independence of him, even to interfere with or to usurp his powers.

\section{THE PLACE OF PHILOSOPHY IN JUDAISM AND CHRISTIANITY}

Christianity and not Judaism threatened the polity in part because Christianity included a transpolitical, philosophical component. Biblical Judaism was wholly unphilosophical (and in this respect inferior to Christianity); Christianity was somewhat philosophical, but its philosophical disputes threatened the stability of the state (making it in a different respect inferior to Judaism). Spinoza's liberalism was designed to combine the political advantages of Judaism with the transpolitical advantages of Christianity: As in Christianity, philosophy would exist, but as in Judaism, philosophy would not threaten the state. Neither Judaism nor Christianity understood that philosophy could exist without threatening the state, because neither properly understood the distinction between public and private spheres. Philosophy could cease to be politically controversial if it could be placed in a private sphere in which it could not interfere with the state (and in which the state could not interfere with it).

In Spinoza's view, the Christian amalgamation of philosophy with religion threatened the stability of the state by making it more difficult for political leaders to control religion. He thought that philosophical religions provide grounds for a whole range of theoretical and metaphysical disputes (necessarily absent from unphilosophical religions) that can potentially endanger the public peace. But political leaders are not normally competent to decide theoretical and metaphysical questions. Thus divisive schismatic disputes are more likely to occur in philosophical religions, and are less likely to be susceptible to resolution by the political authorities. 
Spinoza maintained that philosophy had been incorporated into Christian theology by ambitious clerics who were anxious to increase their own power (at the price of weakening the state's power):

\begin{abstract}
The ecclesiastics took good care that the Christian kings should not assume their authority ... by multiplying the dogmas of religion to such an extent and so blending them with philosophy that their chief interpreter was bound to be a skilled philosopher and theologian, and to have leisure for a host of idle speculations: conditions which could only be fulfilled by a private individual with much time on his hands. ${ }^{17}$
\end{abstract}

Thus Spinoza criticized the politicization of philosophy that resulted from the uses to which it was put in Christianity. Nevertheless, Spinoza praised the existence of philosophy within Christianity by portraying Jesus himself as a philosopher. ${ }^{18}$ Unlike Moses, Jesus "had a clear and adequate perception", ${ }^{19}$ he demonstrated the desirability of theoretical knowledge while exemplifying the possibility of theoretical knowledge. Spinoza's two examples of Christian philosophy thus show Christianity at both its best (Jesus) and its worst (the politically ambitious clerics). Jesus suggests the merit of the Christian understanding of the need to transcend the polity; the clerics suggest the defect of the Christian propensity to interfere with the polity.

Unlike Christianity, Judaism was politically acute but philosophically obtuse; in this it reflected the character of Moses, its greatest prophet. He was not "a philosopher," but "a lawgiver"; as such, "he perceived the method by which the Israelitish nation could best be united in a particular territory, and could form a body politic or state," without "perceiv[ing] these things ... as eternal truths, but [instead] as precepts and ordinances." ${ }^{20}$ Moses was not a philosopher; instead he misunderstood the nature of God, "conceiv[ing $\mathrm{Him}$ ] as a ruler, a legislator, as merciful, just, etc., whereas such qualities are simply attributes of human nature, and utterly alien from the nature of the Deity."21

Moses' followers were politically successful, although (and because) ${ }^{22}$ they were totally unaware of and hence indifferent to the benefits of the philosophical life.

The only respects in which the Hebrews surpassed the other nations, are in their successful conduct of matters relating to government, and in their surmounting great perils solely by God's external aid.... For in respect to intellect ... they held very ordinary ideas about God and nature, so that they cannot have been chosen in this respect, ... therefore their choice ... consisted only in the temporal happiness and advantages of independent rule. ${ }^{23}$ 
Thus in Spinoza's view the Jews had theoretical deficiencies, but their commonwealth nevertheless "possessed many excellent features which might be brought to our notice, and perhaps imitated with advantage."

\section{THE LIBERAL CASE FOR THE JEWISH STATE}

Spinoza commended the Jewish state for its recognition of the importance of attaining the political goods of "temporal happiness and [the] advantages of independent rule." The Jews were wrong to be unaware of transpolitical goods; nevertheless, Spinoza sympathized more with the Jewish emphasis on the polity as the source of all goods than he did with Christian indifference to the polity as the source of no goods: ${ }^{25}$

It is certain that duties towards one's country are the highest that man can fulfil; for, if government be taken away, no good thing can last, all falls into dispute, anger and anarchy reign unchecked amid universal fear. Consequently there can be no duty towards our neighbour which would not become an offence if it involved injury to the whole state, nor can there be any offence against our duty towards our neighbour, or anything but loyalty in what we do for the sake of preserving the state. $^{26}$

The Jewish state rightly exemplified the importance of controlling its subjects' actions; it was equally right to understand that their actions could be controlled regardless of their opinions. The Jewish state thus provided a useful model for the Christian world with regard to both the extent of governmental authority and the limits on it. As legislator, Moses was concerned only with actions, not opinions; he did not care why his subjects obeyed, provided that they obeyed. Thus Moses (unlike Jesus) concerned himself only with the "outward act," not with "mental acquiescence"; whereas Jesus "did not aim at correcting outward actions so much as the frame of mind." ${ }^{27}$ Moses, not Jesus, properly understood the extent of the political sphere. Spinoza proposed that the liberal state adopt the Mosaic and not the Christian standard: "a man's loyalty to the state should be judged, like his loyalty to God, from his actions. ${ }^{, 28}$

Because Judaism was altogether untheoretical, the Jewish state was not embroiled in the theoretical disputes that caused so much political chaos in the Christian world. ${ }^{29}$ For this reason, Spinoza's argument against "law enter[ing] the domain of speculative thought, and opinions 
[being] put on trial" ${ }^{30}$ was a criticism of Christian, not Jewish practice: heresy was a crime among the Christians, not among the Biblical Jews. Opinions were not put on trial among the Biblical Jews; unfortunately (from a transpolitical standpoint), this may have been because there were no opinions to put on trial. ${ }^{31}$

Thus Spinoza aimed to liberate philosophy from political control while subordinating religion to political control. Because the subordination of religion to politics appears to be so illiberal, I must explain why and how Spinoza can have advocated it. He did so as a result of his adoption of a "Jewish" definition of religion-that is, he argued that, properly understood, religion should be placed in the public sphere of actions, not in the private sphere of opinions. He equated religious faith with people's obedience as expressed in their actions. His definition of faith therefore paid heed only to their actions:

\footnotetext{
We can only judge a man faithful or unfaithful by his works. If his works be good, he is faithful, however much his doctrines may differ from those of the rest of the faithful: if his works be evil, though he may verbally conform, he is unfaithful. For obedience implies faith, and faith without works is dead. ${ }^{32}$
}

For this reason, he consistently argued that only "the outward observances of piety ... should ... be determined by the sovereign power alone." By contrast, "inward worship of God and piety in itself are within the sphere of everyone's private rights, and cannot be alienated." ${ }^{33}$ Because Spinoza generally redefined religion so as to exclude speculation therefrom, and to include only moral action and obedience to the law therein, he could argue that religion should be placed in the public rather than the private sphere. ${ }^{34}$ For Spinoza (as was later also the case for Kant), religion is the realm of practical rather than theoretical reason. ${ }^{35}$

The subordination of religion therefore exemplifies Spinoza's twofold liberal strategy of simultaneously strengthening the polity while limiting the sphere of its control. He argued that the political order must be able to control certain of our actions, but only with the aim of keeping the peace (and hence preserving our lives). Because the polity's goal is to promote the security of the individuals who compose it, it is entitled to control our actions (when necessary), but not our opinions, which it must therefore leave free. The Theologico-Political Treatise is thus at once absolutist (in granting the state control of religion) and liberal (in restricting that control to the actions of the state's subjects, whose opinions are therefore uncontrollable). ${ }^{36}$ 
The Jewish state served no transcendent purposes in that it did not attempt to improve the intellect or the moral character of its members. Instead, the benefits that accrued to the subjects of the Jewish state were altogether corporeal. ${ }^{37}$ Noteworthy among the benefits resulting from the Jews' obedience to the Mosaic law was the provision of economic security. The Jewish state "retain[ed] the affections of [its] citizens" by appealing to their "self-interest, the strength and life of all human action." It did so by protecting the private property of its subjects: "Nowhere else did citizens possess their goods so securely as did the subjects of this community." 38 Individual Jews possessed landed property, and possessed it securely, because landowners who had lost their property regained it in the jubilee year. Those impoverished before the jubilee year were provided with charitable assistance by their neighbors. Jewish national solidarity therefore rested not on the abnegation but rather on the recognition of individual economic self-interest. $^{39}$

Thus the Jewish state protected the bodies and material possessions of its subjects, but did not benefit them intellectually or spiritually. ${ }^{40} \mathrm{But}$ in this regard there is no meaningful distinction to be made between the Jewish state and the liberal state. For Spinoza denied that any political arrangement could in and of itself enhance "the knowledge of things" or "the acquirement of the habit of virtue." Instead, "the ends of every social organization and commonwealth are ... security and comfort" ${ }^{\star 41}$ - the very ends achieved by the Jewish state. In emphasizing bodily goods rather than theoretical goods, actions rather than understanding, the Jewish state was not inferior to the liberal state; it was instead the prototype of the liberal state. ${ }^{42}$ The Jewish state was indifferent to the higher intellectual and moral goods; but Spinoza thought that no state could directly promote those goods.

\section{THE "JEWISH" FAILINGS OF THE LIBERAL STATE}

The Jewish state aimed at the goals toward which all states should aim. Spinoza was by no means uncritical of the means it adopted in order to achieve these goals; because of these criticisms, he was far from regarding the Jewish state in all respects as a worthy model for the liberal state. ${ }^{43}$ Subsequent liberal states could correct the political deficiencies of the Jewish state. Nevertheless, it is more illuminating to 
consider the deficiencies that liberal states necessarily share with the Jewish state. The liberal state could more effectively achieve the limited goals sought by the Jewish state, but not the transcendent goals of which Judaism was oblivious, because such goals are by definition transpolitical. Even the ideal liberal state is in decisive respects as limited as was the Jewish state.

The subjects of the liberal state (unlike the subjects of the Jewish state) may be aware of transpolitical goals, but as a state, the liberal state must ignore them. No state, Jewish or liberal, can achieve the greatest good, because the greatest good (moral and intellectual perfection) is necessarily a private good.

Spinoza criticized Judaism for its indifference to the greatest good. But because he equated Judaism with the polity, his critique of Judaism is also a critique of the state-even the liberal state. He couched his critique in terms familiar from Pauline theology, contrasting carnal, particularistic, legalistic Judaism with spiritual and universalistic Christianity. But it is important to realize that Christianity is spiritual and universalistic because it is apolitical; and Judaism carnal, particularistic, and legalistic because it is political.

Moses' political teaching was particularistic, whereas Jesus' apolitical teaching was universalistic. The "moral precepts" that Moses advocated "appear not as moral doctrines universal to all men, but as commands especially adapted to the understanding and character of the Hebrew people, and as having reference only to the welfare of the kingdom." By contrast, the apolitical Jesus "was sent to teach not only the Jews but the whole human race." 44

Particularistic political law is morally inferior to universalistic, apolitical "law" for the same reason that Mosaic doctrine suffers by comparison with Christian doctrine. True moral virtue, identical to true intellectual virtue, is transpolitical, and cannot be produced by the state's coercion and control of its subjects. Instead it is the product of the individual's rational apprehension of the universe and his or her role in it; as such it is accessible to all individuals in all communities. "To all men absolutely was revealed the law under which all lived - namely, the law which has regard only to true virtue, not the law established in respect to, and in the formation of, a particular state." 45

Political law is morally inferior not only because it addresses a smaller, particularistic audience, and because it aims only at security and self-preservation, but also because it rests upon compulsion. This was true of the Mosaic law: Moses inculcated his precepts "not like a philosopher, as the result of freedom, but like a lawgiver compelling his 
subjects to be moral by legal authority." ${ }^{46}$ But this statement is not only a moral criticism of Moses; more importantly, it is a moral criticism of political legislation in general. For in this respect all legislators act just as Moses acted:

\begin{abstract}
As the true object of legislation is only perceived by a few, and most people are almost incapable of grasping it, . . . legislators, with a view to exacting general obedience, have wisely ... promise[d] to the observers of the law that which the masses chiefly desire, and threaten[ed] its violators with that which they chiefly fear: thus endeavoring to restrain the masses . . like a horse with a curb; whence it follows that the word law is chiefly applied to the modes of life enjoined on men by the sway of others; hence those who obey the law are said to live under it and to be under compulsion. ${ }^{47}$
\end{abstract}

We have seen that the motive for obedience to state law is politically irrelevant. It nevertheless is morally relevant. One finds in Spinoza a distinction between legality and morality that calls to mind Kant: Morality connotes doing the right thing for the right reason, legality doing the right thing (regardless of one's reason). It is true (in the parlance of contemporary liberalism) that "you can't legislate morality"; this points, however, not to the irrelevance of morality, but instead to the inescapable shortcomings of legislation.

Political law is necessarily heteronomous (to borrow again from Kant). Because most people will not do the right thing for the right reason, the law must instead constrain them to do the right thing for the wrong reason - that is, to avoid punishment. Because political law must compel obedience, political law can never promote genuine morality. Only individuals' development of their reason (which the law can neither hinder nor assist) can lead them to do the right thing for the right reason.

Because political law must compel obedience, it also cannot promote genuine knowledge. State law must be obeyed, regardless of the motive for its being obeyed. Therefore, if popular belief in possibly erroneous doctrines promotes obedience, popular belief must remain unexamined. The doctrine of salvation through works, to give an example, "cannot be proved by reason whether it be true or false"; nevertheless, it must be accepted, because it "has proved such a comfort to those whose reason is comparatively weak, and such a benefit to the state." ${ }^{48}$ The state's goal must be to secure the obedience of "those whose reason is comparatively weak"; the state's goal is not, because it cannot be, to strengthen their reason.

Moral and intellectual perfection will be more likely in the liberal state than they were in the Jewish state; this represents a significant improvement over the Jewish state. Nevertheless, the significance of the 
improvement should not be overstated. Spinoza did not expect many more people in any society to seek to achieve such perfection than did the Biblical Jews, who "were all uncultivated and sunk in a wretched slavery. ${ }^{\wedge 9}$ It was likely that ignorance would always be the rule in society, enlightenment very much the exception. "The fickle disposition of the multitude almost reduces those who have experience of it to despair, for it is governed solely by emotions, not by reason." ${ }^{50}$

It is likely, Spinoza contended, that moral and intellectual perfection will always be possible only for a few, and only as a result of their individual efforts. The liberal state, like the Jewish state, can therefore not assist in the achievement of the greatest goods-the transpolitical goods.

\footnotetext{
Simplicity and truth of character are not produced by the constraint of laws, nor by the authority of the state, no one the whole world over can be forced or legislated into a state of blessedness; the means required for such a consummation are faithful and brotherly admonition, sound education, and, above all, free use of the individual judgment. ${ }^{\mathrm{sl}}$
}

It is Spinoza's belief in a greatest good that makes him so different from many liberals, and so interesting in comparison to them. Like other liberals, Spinoza limited the ends that the state is designed to achieve. But unlike other liberals (Hobbes being the most prominent in this respect), he did so not because he believed that only limited ends were attainable. Spinoza believed in an unlimited end, in a summum bonum; he believed, however, that it was necessarily a transpolitical end. "Knowledge of things," related to "the acquirement of the habit of virtue," 52 is a great good that politics is unable to help us attain. "The laws of human nature" alone are necessary and sufficient to ensure "the government of the passions" (with which "the acquirement of the habit of virtue" is equated). Only such physical and psychological laws can lead to the development of reason, which can govern the passions; ${ }^{53}$ political laws do not govern the passions, but instead merely play some passions (e.g., fear of punishment) off against others. ${ }^{54}$ "True happiness" was not achieved by the Jewish state, and (more importantly) could be achieved by no state, because "our highest good" consists wholly in "the knowledge of God," ${ }^{55}$ which no government can teach us. "In regard to intellect and true virtue, every nation is on a par with the rest." ${ }^{56}$ A state can do no more than enable "every member" to "be free," because true freedom connotes "living with free consent under the entire guidance of reason." The state cannot free its subjects; only they can free themselves. Freedom results from private, voluntary action; a man "may ... be free" 
only "if he will" be free. The political contribution to human freedom is therefore smaller than one might expect. "Whatever be the social state a man finds himself in, he may be free." ${ }^{57}$ A "social state" is apparently necessary for freedom, but any social state, regardless of its form of government, could suffice. The polity is important in that it alone can achieve the "Jewish" ends of the security and preservation of individuals; it is unimportant in that it is altogether incapable of achieving the "Christian" end of moral and intellectual perfection.

Spinoza's liberalism thus accepts an important but melancholy political truth taught in Spinoza's view by Judaism: The polity is necessary because humans stand in need of bodily protection against and preservation from one another. We can be reasonably sure of protection against one another only if we are all subjected to legal constraint and coercion. For this reason, Spinoza has been said to have conceived of political society as a "society of slaves." ${ }^{58}$ For the same reason, Spinoza's "implicit program" can be said to envision "a people so completely ruled by the rational apprehension of the community of their interests that the state as a coercive force would wither away." ${ }^{59}$ It was only Spinoza's implicit program, however, because it was only what he would have wished to occur, not what he would ever have expected to occur.

\section{THE YOUNG MARX'S CRITIQUE OF JUDAISM AND LIBERALISM}

Spinoza's implicit program came to be the explicit program of Karl Marx. ${ }^{60}$ Marx believed that the liberal state, toward whose moral shortcomings Spinoza had pointed, would eventually be abolished and transcended, and replaced by communist society. But the young Marx's radicalization of Spinozist political philosophy, it is important to note, is built on Spinozist premises. For the young Marx, like Spinoza, partially equated liberalism with Judaism; and this equation, the source of Spinoza's implicit critique of the liberal state, also figured in the young Marx's far harsher explicit critique. Both Spinoza and Marx were "non-Jewish Jews" who rejected the Judaism of their forefathers; ${ }^{61}$ in each case the rejection had political implications as well as theological ones. Yet on the basis of similar critiques of Judaism, Spinoza and the young Marx arrived at very different political positions.

The young Marx criticized Judaism in his early essay, "On the Jewish Question." The harshly polemical tone of his attack upon Judaism there 
has proved to be an embarrassment to his sympathizers and a godsend to his detractors. But as Spinoza suggests, our goal should be "not to mock, lament, ... execrate [or exonerate], but to understand human actions." ${ }^{62}$ To understand the young Marx's "human action" in writing "On the Jewish Question," one "must disregard both cold war propaganda ... and the view that 'to designate Marx as an anti-Semite is nothing but cold war propaganda.' " ${ }^{63}$ This can be accomplished by noting that the substance of the young Marx's critique of Judaism does not significantly differ from Spinoza's ${ }^{64}$ (though the tone of course is incomparably more strident). Once this is realized, it should not be appreciably more difficult to discuss the young Marx's understanding of Judaism dispassionately than to discuss Spinoza's.

Like Spinoza, the young Marx emphasized what one might call (at the risk of an oxymoron) Jewish philistinism. The young Marx asserted that Judaism "could not, by its very nature, find its consummation in theory, but only in practice, just because practice is its truth." For the young Marx as for Spinoza, Judaism is the altogether untheoretical "religion of practical need," ${ }^{65}$ a materialistic as opposed to a spiritual religion. ${ }^{66}$ Like Spinoza, the young Marx saw in Judaism a legalistic, heteronomous religion in which the law had to be obeyed, but was never properly understood: "The law, without basis or reason, of the Jew, is only the religious caricature of morality and right in general, without basis or reason; the purely formal rites with which the world of selfinterest encircles itself." ${ }^{67}$

Furthermore, the young Marx as well as Spinoza pointed to the similarity between Judaism and liberalism: Both were seen as materialistic, legalistic expressions and defenses of human self-interest. "Practical need, egoism" was in Marx's view both "the basis of the Jewish religion" and the "principle of [liberal] civil society." ${ }^{68}$ Thus the young Marx held that the existence of civil society, the economic realm in which individuals are free to pursue their material self-interest, demonstrates that "the practical Jewish spirit_Judaism or commercehas perpetuated itself in Christian society and has even attained its highest development there." ${ }^{69}$

In addition, the role played by the law in the liberal state is no different from the role played in Judaism by the Jewish law; state law like religious law is heteronomous, motivating subjects by their fear of punishment. "Here again the supreme condition of man is his legal status, his relationship to laws which are valid for him, not because they are the laws of his will and nature, but because they are dominant and any infraction of them will be avenged." 70 
In all of the above respects, the young Marx's conception of the liberal state as it exists in practice is not unlike Spinoza's earlier vision of it. The two accounts are as close as they are because of Spinoza's and the young Marx's similar understandings of Judaism, and their similar perceptions of the likeness between Judaism and liberalism. More importantly, both Spinoza and the young Marx agreed that it was morally and intellectually essential for human beings to ask more of themselves than the liberal state could ask of them, or in some way to transcend the limited goals of the liberal state. Of equal importance, however, is the disagreement between Spinoza and the young Marx concerning the means of transcending the liberal state.

The young Marx criticized what he referred to as "political emanicipation," by which he meant the program for the creation of the liberal state - the abolition of governmental restraints on freedom of speech and religion, the abolition of feudal restraints on the alienability of property, the opening of careers to talent, the establishment of governmental accountability to the popular will. It is true that he recognized that "political emancipation certainly represents a great progress." "But more fundamentally, he stressed the limits to that progress: "Political emanicipation is not the final and absolute form of human emancipation." 72

The defect of political emancipation, in the young Marx's view, is that "a state may be a free state without man himself being a free man." Spinoza too, we recall, differentiated between a free state and a free man: even the freest state (i.e., the liberal state) could do no more than enable every member to be free, "if he will." ${ }^{74}$ Spinoza and the young Marx agreed that the free state does not automatically produce free men, and that free men are superior to those who are not free: The questions dividing Spinoza and the young Marx concern the meaning of freedom, and what men must do in order to be free.

\section{THE "CHRISTIAN" TRANSCENDENCE OF COMMUNIST SOCIETY}

The young Marx moved beyond liberalism by rejecting the publicprivate distinction, and the bleak view of the limitations of public life that lay behind it. Rejecting the liberal Spinozist opposition of public to private, the young Marx believed that communist society would synthesize public and private; in communist society, social life would no longer be limited and "Jewish," but would instead be transcendent and 
"Christian." The transcendence that Spinoza had restricted to the philosophical few, thinking privately, would under communism be attained by all, acting publicly.

This is apparent in a number of respects. The young Marx ceased to oppose philosophical activity to political activity. Instead he argued that revolutionary public activity would achieve the transcendent goal of philosophy: "Philosophy can only be realized by the abolition of the proletariat, and the proletariat can only be abolished by the realization of philosophy." ${ }^{75}$ Marx was able to synthesize philosophy and politics because he no longer saw politics, as did Spinoza, as an unequivocally "Jewish" phenomenon. Instead he thought that "the perfected Christian state" is "the democratic state," "in the sense that man, not merely one man but every man, is there considered a sovereign being, a supreme being." ${ }^{76} \mathrm{He}$ considered democracy to be "Christian" because it is based upon the recognition of the equality and sovereignty of man. He thought human equality to be "Christian" because of Christianity's denial that any single people could be regarded as God's chosen people; he thought human sovereignty to be "Christian" because of Christianity's assertion that God had become man. ${ }^{77}$

The young Marx did not, of course, equate "the perfected Christian state" with communist society. He did not do so for several reasons: among them is his belief that the "sovereign being" in "political democracy" is "unsocial man, ... alienated ... man who is not yet a real species-being." ${ }^{78}$ In other words, the "Christian" democratic state is corrupted by the influence of "Jewish" civil society. ${ }^{79}$ The young Marx therefore believed that the "Christian" component in the liberal community was relatively impotent; but the fact that he identified political democracy as "Christian" enabled him to discern a potentially transcendent element in public life, the existence of which Spinoza had denied. ${ }^{80}$

Communist public life would be transcendent, the young Marx thought, because it would transcend the limitations characteristic of both Jewish and liberal public life. We have seen that for Spinoza, the limitations of public life resulted from its particularistic and legalistic character. Communist society, by contrast, would abolish both particularism and legalism. "Religion, family, state, law, ... are only particular modes of production.... The positive transcendence of private property as the appropriation of human life is, therefore, the positive transcendence of all estrangement-that is to say, the return of man from religion, family, state, etc., to his human, i.e., social mode of existence." ${ }^{81}$ The young Marx thought that universalism would be 
possible on the basis of cooperative social activity, not just (or at all) on the basis of contemplative isolation. He would have said that Spinoza (like Feuerbach) understood practice "only in its dirty-judaical manifestation." Thus Spinoza did "not grasp the significance of 'revolutionary,' of practical-critical activity." "The standpoint of the old [i.e., Spinozist] materialism [was] 'civil' society; the standpoint of the new [i.e., Marxist materialism is] human society, or socialised humanity." 82

One can readily comprehend the young Marx's belief in the superiority of "human society" to " "civil' society." What is less comprehensible, of course, is his belief in the certainty or the probability or even the possibility of the advent of "human society." As the young Marx envisioned it, "human society" was to consist of "species-being[s]," 84 humans who would coexist in spontaneous and total unity and harmony. Their unity and harmony, he believed, would render their supervision and control by political authority superfluous, and would therefore make possible the abolition and transcendence of political authority.

In believing that politics could be abolished, the young Marx made an assumption that $I$, like many others, find incredible. Because he believed in total and spontaneous unity, he did not take seriously the possibility that political coercion at least in some degree might be an unavoidable necessity of human life. Instead he asserted that "punishment, coercion, is contrary to human conduct." ${ }^{85}$ Because he believed in total and spontaneous unity, he also did not take seriously the possibility that the recognition of individual rights might be desirable in any social order, and was not simply an epiphenomenon of an undesirable bourgeois social order. The young Marx instead "assume[d] that any society in which the potential for interpersonal conflict is serious enough to warrant the establishment of rights is a deeply defective society." ${ }^{86}$ The young Marx, in short, was insufficiently aware of either the state's need to control individuals or of individuals' need to be protected against the state.

These criticisms of the young Marx are, of course, quite familiar. The consideration of the young Marx's and Spinoza's contrasting discussions of Judaism and Christianity is useful in that it helps in explaining a source of the shortcomings in the young Marx's thought that occasion the criticisms. I have suggested that the young Marx attempted to present a revisionist "Christian" interpretation of public life, and that it is an unsuccessful and unpersuasive interpretation of public life. The deficiencies of the political thought of the young Marx stem from its "Christian" character ${ }^{87}$ in that they are akin to the deficiencies for which 
Spinoza criticized Christianity. The young Marx, like Christianity as portrayed by Spinoza, desired an end that public life cannot provide (spontaneous and uncoerced total unity), and devalued ends that it can provide (protection of individual life and provision of individual security).

Spinoza made fewer claims for public life than did the young Marx. No one should accept Spinoza's equation of liberal politics with Judaism, because no one should agree that there is nothing transcendent in Judaism. Liberals can and must agree, however, that the sort of transcendent total unity advocated and anticipated by the young Marx cannot be achieved in public life ${ }^{88}$ - whatever discontents with liberal public life this has caused, can cause, must cause. Spinoza and the young Marx both erred grievously in their depiction of Judaism-but those living in a more or less Spinozist society, as opposed to a more or less Marxist society, can at least be grateful that the Spinozist error has been more fruitful politically. There is a sense in which Judaism does claim to achieve a transcendent unity between believers and their God; there is not and should not be a comparable sense in which liberal states attempt to achieve a transcendent unity between citizens and their community.

\section{NOTES}

1. I must emphasize at the outset that my argument is intended to apply only to the young or humanist Marx. Questions concerning the character of Judaism and Christianity, and their respective relationships to liberalism and democracy, were of vital concern to the author of "On the Jewish Question"; it is clear that such questions ceased to be of concern to the historical materialist into whom Marx shortly thereafter developed. Uncharacteristic of Marx's later work as his early essays are, they are nevertheless significant in that they reveal the grounds for his belief in the superiority of communist society.

2. See Sylvain Zac, Philosophie, Théologie, Politique Dans l'Oeuvre de Spinoza (Paris: J. Vrin, 1979); p. 156.

3. A Theologico-Political Treatise, trans. R.H.M. Elwes, in The Chief Works of Benedict de Spinoza, Vol. 1 (New York: Dover, 1951); chap. 20, p. 259. This work will henceforth be identified as $T$-P; chapter number and page number in the Dover edition will be provided.

4. "On the Improvement of the Understanding," trans. R.H.M. Elwes, in Spinoza, Ethics, ed. James Gutmann (New York: Hafner, 1949); p. 6.

5. The injustice of Spinoza's critique of Judaism can in part be explained in terms of his rhetorical intention. Inasmuch as he wrote for a predominantly Christian audience, it is hardly surprising that he should to some extent have appealed to Christian prejudices, wherein Judaism was understood as a religion of the law, not of the spirit. See Leo Strauss, 
Spinoza's Critique of Religion (New York: Schocken, 1965): 20, and Emil L. Fackenheim, To Mend the World: Foundations of Future Jewish Thought (New York: Schocken, 1982); pp. 44-45. Spinoza's Christian readers would have been willing to accept the political superiority of Judaism to Christianity only if in turn their belief was confirmed that in other moral and intellectual respects Christianity was superior to Judaism. Thus Spinoza's assertion of the moral and intellectual excellence of Christianity may well have been somewhat disingenuous; but his belief in Judaism's moral and intellectual deficiency was undoubtedly in large measure genuine. (In addition, Spinoza's personal experience may help to explain one particularly idiosyncratic aspect of his interpretation of Judaism: in stressing the irrelevance of belief within Biblical Judaism, Spinoza may have wished to suggest that his Jewish excommunicators were as faithless to their tradition, as influenced by Christianity, as he was himself. I say this because Spinoza's excommunicators did emphasize his beliefs: they spoke of his "evil opinions," of their inability "to bring him to any better way of thinking." See the text of the proclamation of Spinoza's excommunication, in J. E. Woodbridge, "Spinoza," in Ethics, p. xxiii.)

Because I deny the accuracy of many of Spinoza's (and also the young Marx's) more offensive and more imaginative characterizations, I shall occasionally be placing the adjectives "Jewish" and "Christian" within quotation marks. The reader should in any event realize that the characterizations are Spinoza's and the young Marx's-not mine.

6. Even if it is true that liberal politics is defective because limited and "Jewish," one might still defend liberalism as a whole by claiming that it transcends political limits, and can therefore be considered "Judeo-Christian." Spinoza would have sympathized with this defense: he agreed that the liberal state, like the Biblical Jewish state, was to understand the need to control its subjects' actions by securing its subjects' obedience to its laws; but unlike the Biblical Jews, he hoped, at least some of the subjects of the liberal state would share the "Christian" understanding of the need privately to obtain a transcendent, transpolitical moral and intellectual perfection. Thus the public surface of the liberal state was to be "Jewish," the private interior of liberal society "Christian." In other words, one can regard Spinoza's liberalism as a political synthesis developed out of two partially true contradictory theologies. Thus Spinoza thought that his liberalism was truer than either the Judaism or the Christianity upon which it was in a sense based. (Consider the allusion in Strauss, Spinoza's Critique of Religion; p. 17, to the view of Spinoza as "a thinker and a saint who was both a Jew and a Christian and hence neither." See also Fackenheim, To Mend the World; p. 49.)

But this solution provided by liberal society to the defects of the liberal state may not be altogether successful; one would at least want to know how many members of liberal society attempt privately and voluntarily to achieve such perfection. See pp. 70-71 below.

7. See Sylvain Zac, Spinoza et L'Interprétation de L'Écriture (Paris: Presses Universitaires de France, 1965); p. 155.

8. See Strauss, Spinoza's Critique of Religion, p. 19: “'The center of the whole [theologico-political] treatise' is the disparagement of Moses and the idealization of Jesus." Strauss quotes here from Hermann Cohen's interpretation of Spinoza, to be discussed in note 25 below. We will see that in addition to disparaging Moses and idealizing Jesus, Spinoza can also be said to have done the reverse.

9. $T$ - $P$, chap. 7, p. 105.

10. One could, however, contend that the Ethics, unlike the Theologico-Political Treatise, suggests Spinoza's sympathy with Jesus, and not with Moses, in that it explains how the individual may be free regardless of the political order. This is both true and very much to the point: it shows Spinoza's ambivalence about politics (caused by his awareness 
of the many benefits that the political order cannot bestow), which can be explained in terms of his belief in the partial superiority of Christianity to Judaism.

11. $T$ - $P$, chap. 17, p. 217.

12. T-P, chap. 19, p. 255.

13. See Robert J. McShea, The Political Philosophy of Spinoza (New York and London: Columbia University Press, 1968); p. 181.

14. $T$-P, chap. 19 , p. 245 .

15. $T$ - $P$, chap. 19, p. 254.

16. $T-P$, chap. 18 , pp. $237-38$, chap. 19 , pp. $255-56$.

17. $T$ - $P$, chap. 19, p. 255 .

18. Spinoza's understanding of Jesus as a philosopher is discussed by the following authors: Fackenheim, To Mend the World; p. 38, Shlomo Pines, "Spinoza's Tractatus Theologico-Politicus, Maimonides and Kant," Scripta Hierosolymitana 20 (1968); p. 22, and Zac, Spinoza, pp. 190-93. They all agree that Spinoza had to violate his rule of Biblical exegesis in order to understand Jesus in this way; if "our knowledge of Scripture must ... be looked for in Scripture only" ( $T$ - $P$, chap. 7, p. 100), one cannot say that Jesus was a philosopher. Pines, p. 45, explains why Spinoza insisted on this interpretation of Jesus: "Spinoza had to turn Christ into a philosopher in order to be able to claim the supreme religious sanction for his universal religion which, as he believed, would eliminate religious conflicts and persecutions and give the philosopher a secure status in the community."

19. $T$-P, chap. 4 , p. 64 .

20. $T$ - $P$, chap. 2 , p. 39 , chap. 4 , pp. $63-64$.

21. $T$ - $P$, chap. 4 , p. 64 ; cf. chap. 15 , p. 193 , chap. 19 , p. 248.

22. It would be wrong to suggest that Spinoza believed that philosophical knowledge was wholly without political utility. All of the very serious political failings that afflicted the Jewish state (discussed in note $\mathbf{4 3}$ below) could conceivably have been avoided if the Jewish masses or their leadership had been more enlightened, more receptive to philosophic knowledge. Nevertheless, states in which theory is absent have the political advantage that potentially divisive theoretical disputes are absent as well. As we learn from the Bible, there are advantages to not having eaten from the fruit of the tree of knowledge. We learn from Spinoza (though assuredly not from the Bible) that the Biblical Jews possessed those advantages. Spinoza could have said of Jewish ignorance of theory what Kant, Grounding for the Metaphysics of Morals, trans. James W. Ellington (Indianapolis and Cambridge: Hackett, 1981); p. 16, said of innocence: It "is a glorious thing; but, unfortunately, it does not keep very well and is easily led astray." Spinoza wrote after ignorance had ended and theory had come into being; his project was to make the creation of public and private spheres persuasive to his readers, so as to enable them to enjoy the (private) advantages of theory while avoiding its potential (public) inconveniences.

23. $T$-P, chap. 3 , pp. $46-47$; see also chap. 11 , p. 164: "the Jews . . despised philosophy."

24. $T$ - $P$, chap. 18, p. 237.

25. Hermann Cohen failed to take sufficient note of this fact in his critique of Spinoza's interpretation of Judaism. See "Spinoza über Staat und Religion, Judentum und Christentum," in his Jüdische Schriften (Berlin: Schwetschke, 1924), vol. 3: 360. Cohen correctly observed that for Spinoza, "the Jewish religion is only a Jewish political teaching," but he incorrectly understood this as nothing but an attack upon Judaism. Instead, one must realize that for Spinoza, the Christian religion is not even a Christian political teaching. Cf. also ibid., pp. 357-358, and Strauss, Spinoza's Critique of Religion; 
pp. 21-22. Fackenheim, with whose interpretation of Spinoza I agree in many respects, also errs here: he notes the relevance only of Spinoza's critique of Judaism, but not of his complementary critique of Christianity, to Spinoza's argument in behalf of liberalism.

26. $T$ - $P$, chap. 19 , p. 249.

27. $T$ - $P$, chap. 5, p. 70 , chap. 7 , p. 105.

28. $T$-P, chap. 20, p. 261.

29. Cf. Zac, Philosophie, pp. 175-76.

30. $T$ - $P$, Preface, p. 5.

31. In this context, consider also $T$-P, chap. 18: Its title proclaims that "certain political doctrines are [to be] deduced" "from the commonwealth of the Hebrews." Yet when demonstrating (p. 241) that "the most tyrannical governments are those which make crimes of opinions," Spinoza referred for examples not to "the commonwealth of the Hebrews," but instead to Pontius Pilate and Jesus, and to the Pharisees and Sadducees. One may infer that the Biblical Jewish state did not "make crimes of opinions"; conceivably, however, this was because opinions did not exist in it.

32. $T$ - $P$, chap. 14 , p. 185.

33. T-P, chap. 19, p. 245.

34. Spinoza failed wholly to exclude speculation from religion as he redefined it. His failure here was inevitable: Obedience requires someone or something to be obeyed, and we cannot avoid speculating as to who or what that someone or something is. See the seven dogmas of Spinoza's "universal religion" ( $T$ - $P$, chap. 14, pp. 186-187). See also Cohen, "Spinoza über Staat und Religion;" pp. 295-302, for a persuasive critique of Spinoza's inconsistency in differentiating religion from speculative knowledge.

35. This comparison is suggested by Pines, "Spinoza's Tractatus;" p. 51.

36. The compatibility of liberalism and absolutism (indeed, the dependence of liberalism upon absolutism) with respect to Locke's political philosophy is convincingly argued for in Robert Kraynak, "John Locke: From Absolutism to Toleration," American Political Science Review 74 (1980); pp. 53-69. See especially p. 68.

37. $T$ - $P$, chap. 3, p. 47.

38. $T$ - $P$, chap. 17 , p. 230.

39. Spinoza is badly misunderstood by some of his commentators on this point: Lewis Samuel Feuer, Spinoza and the Rise of Liberalism (Boston: Beacon Press, 1958); p. 127, speaks of "the communistic law of the jubilee": André Malet, Le Traité ThéologicoPolitique de Spinoza et la Pensée Bihlique (Paris: Société Les Belles Lettres, 1966): 259. refers to Jewish "agrarian communism." It is true that legislation aimed at maintaining equality among private landholdings is not capitalistic (because it seeks only to preserve the economic status quo), but as Marx and Engels would have been the first to point out, such legislation is not truly communistic either. See "Manifesto of the Communist Party," in Robert C. Tucker, ed., The Marx-Engels Reader (New York: Norton, 1978); p. 490: Communism requires "abolition of property in land," not maintenance of equalized private property in land.

40. $T$ - $P$, chap. 3 , pp. $46-47$.

41. $T$ - $P$, chap. 3 , pp. $45,47$.

42. Feuer, Spinoza and the Rise of Liberalism, p. 130, emphasizes different aspects of the Biblical commonwealth than I do, but in this respect arrives at a similar conclusion: "The Hebrew theocracy, in Spinoza's analysis, was a pilot state in the principles of the [liberal Dutch] Republican party."

43. Among Spinoza's political criticisms of the Jewish state, consider the following: 1) it was xenophobic ( $T$ - $P$, chap. 1 , p. 24 , chap. 17, p. 229); 2) at its outset it was ruled 
absolutely by one man, with no constitutional provisions checking and balancing his power (chap. 5, p. 75); 3) Moses's creation of a separate priestly tribe created discord within the community, and ultimately made it impossible to maintain political control of the priesthood (chap. 17, pp. 232-36); 4) the Mosaic law regulated the actions of its subjects so comprehensively that it "left nothing to the free choice of individuals" (chap. 5, p. 75). At least the second and the fourth of these criticisms are mitigated by Spinoza's recognition of what he took to be the inferior human material with which Moses had to deal: The Jews "were entirely unfit to frame a wise code of laws and to keep the sovereign power vested in the community; they were all uncultivated and sunk in a wretched slavery, therefore the sovereignty was bound to remain vested in the hands of one man who would rule the rest and keep them under constraint, make laws and interpret them" (chap. 5, p. 75). But to say that Moses's rule may have been defensible in view of the circumstances is not to say that it would be a form of rule worthy of adoption under superior circumstances. See Zac, Philosophie, p. 101.

44. $T$-P, chap. 5 , p. 70 , chap. 4 , p. 64 ; cf, chap. 12 , p. 170.

45. $T$-P, chap. 3 , p. 53.

46. $T$ - $P$, chap. 2 , p. 39.

47. $T$ - $P$, chap. 4 , p. 58 .

48. $T-P$, chap. 15, pp. $195,197$.

49. $T$-P, chap. 5 , p. 75 .

50. T-P, chap. 17, p. 216.

51. $T-P$, chap. 7 , p. 118.

52. $T$ - $P$, chap. 3 , p. 45.

53. See Ethics, pt. 5, note to proposition 4, note to prop. 20.

54. See Ethics, pt. 3, note to prop. 39, pt. 4, prop. 7, note 2 to prop 37.

55. $T$ - $P$, chap. 3 , p. 48 , chap. 4 , p. 59.

56. $T$ - $P$, chap. 3 , p. 56.

57. $T$-P, chap. 16 , p. 206 , note 27 to chap. 16 , p. 276.

58. Zac, Philosophie, p. 98; the quoted words are Léon Brunschvicq's. Zac rightly goes on to point out that Spinoza identified the polity with slavery only on one level; on another level, Spinoza (like Locke) distinguished between subjects, sons, and slaves. See $T$-P, chap. 16, pp. 206-207.

59. McShea, Political Philosophy of Spinoza, p. 133.

60. In fact it was Engels and not Marx who wrote that the state would wither away. For other purposes, the distinction between Engels's term Absterben des Staates and Marx's term Aufhebung des Staates would be significant; for my purposes here, the fact that Marx's term "refers to the abolition and transcendence ... of the state" is sufficient. See Shlomo Avineri, The Social and Political Thought of Karl Marx (Cambridge: Cambridge University Press, 1970); p. 203.

61. The kinship between Spinoza and Marx is noted (but, we shall see, exaggerated) by Isaac Deutscher, in The Non-Jewish Jew and Other Essays, ed. Tamara Deutscher (London, New York, and Toronto: Oxford University Press, 1968). See p. 26: Deutscher describes Spinoza and Marx (as well as Heine, Rosa Luxemburg, Trotsky, Freud, and implicitly, one presumes, Deutscher) as "Jewish heretic[s] who transcend Jewry.... They all went beyond the boundaries of Jewry. They all found Jewry too narrow, too archaic, and too constricting. They all looked for ideals and fulfillment beyond it." This is true; but to differentiate Marx from Spinoza by saying (p. 32) that Marx's "idea was as universal as Spinoza's, yet advanced in time by two hundred years" is either to ignore a serious political debate between the two thinkers or else to prejudge it in Marx's favor. 
62. A Political Treatise, trans. R.H.M. Elwes, in The Chief Works, vol. 1, chap. 1, paragraph 4.

63. Fackenheim, Encounters Between Judaism and Modern Philosophy: A Preface to Future Jewish Thought (New York; Basic, 1973); p. 250. The emphasis is Fackenheim's.

64. One might, however, argue that the target differs, in that the young Marx in his essay described not the Biblical Jews, but their descendants thousands of years later, who resided in nineteenth-century Europe. This is true; it is also true that Spinoza, unlike Marx, actually knew a great deal about Judaism (notwithstanding the ways in which he abused his knowledge in criticizing Judaism). Nevertheless, even though Spinoza and Marx differed greatly in the extent of their knowledge of Judaism, and even though the Jews whom Spinoza and Marx discussed lived in very different eras under radically different conditions, it is still the case that Jews as described by the young Marx share many characteristics with Jews as described by Spinoza.

Because Spinoza's name does not appear in the essay "On the Jewish Question," it would be rash to assert that the young Marx's criticism of Judaism there directly derives from Spinoza's model. We do know, however, that Marx had read Spinoza by the time he wrote the essay. He referred to Spinoza in his 1841 doctoral dissertation, "Difference Between the Democritean and Epicurean Philosophy of Nature," and again in two of his 1842 newspaper articles, "Comments on the Latest Prussian Censorship Instruction" (his first published piece) and his "Leading Article in No. 179 of the Kölnische Zeitung." (See Marx and Engels, Collected Works, Vol. 1 [New York: International Publishers, 1975];

pp. $54,119,201$.) From the last two of these references it is apparent that Marx was acquainted with the Theologico-Politico Treatise in particular.

But in any case, my argument does not depend on evidence of direct influence by Spinoza upon the young Marx. For Spinoza would certainly have influenced the young Marx indirectly, as a result of his influence on German idealist philosophy, especially Hegel's. With particular reference to the young Marx's critique of Judaism, one should consider an observation in Fackenheim, Encounters, p. 89: "Kant and Hegel ... took their cue on 'Jewish legalism' from Spinoza and Moses Mendelssohn." (See also Cohen, Spinoza über Staat und Religion, pp. 362, 370-371.) Furthermore, and most importantly, the attack upon Judaism promulgated by both Spinoza and the young Marx clearly derives from Christian stereotypes of Judaism. For this reason, even if we knew that Marx had never heard of Spinoza, the similarity between Spinoza's and the young Marx's critiques of Judaism would still not be coincidental; it would simply reflect the extent to which Spinoza and the young Marx were (perhaps unwittingly) each independently influenced by arguably the most influential Jewish apostate of them all-the apostle Paul.

65. "On the Jewish Question," in The Marx-Engels Reader, p. 51. This work will henceforth be identified as "JQ." Here as elsewhere, the emphases in quotations from Marx appear in the translations.

66. See also Marx's "Theses on Feuerbach," in The Marx-Engels Reader, p. 143: "Feuerbach ... regards the theoretical attitude as the only genuinely human attitude, while practice is conceived and fixed only its dirty-judaical manifestation."

67. “JQ," p. 51.

68. “JQ," p. 50.

69. “JQ," p. 50.

70. “JQ," p. 51.

71. “JQ," p. 35.

72. “JQ," p. 32.

73. “JQ," p. 32. 
74. T-P, chap. 16, p. 206.

75. "Contribution to the Critique of Hegel's Philosophy of Right: Introduction," in The Marx-Engels Reader, p. 65.

76. “JQ," pp. 36, 39.

77. If Marx is to be correctly understood, however, one must realize that his use of the term "Christian" here is altogether metaphorical. This becomes apparent in "JQ," p. 36, where he explains that "the perfected Christian state is not the so-called Christian state which acknowledges Christianity as ... the state religion ... ; it is, rather, the atheistic state [i.e., the state in which church is separated from state]."

78. “JQ," p. 39.

79. Thus in the young Marx's view, the surface of the liberal community - the stateis "Christian," whereas its interior--civil society-is "Jewish"; his view can be compared with Spinoza's contradictory understanding, outlined in note 6 above.

80. For this reason it is highly appropriate that one of Marx's most thoughtful interpreters describes him as "the last of the Lutherans"-meaning by this that Marx (unlike Spinoza) denied that social life necessarily presupposed external coercion of the individual. See Avineri, Social and Political Thought of Karl Marx, p. 202. (On Marx's rejection of coercion, see also p. 76 below.)

81. "Economic and Philosophic Manuscripts," in The Marx-Engels Reader, p. 85. See also Leszek Kolakowski, Main Currents of Marxism: Its Rise, Growth, and Dissolution, vol. 1, trans. P. S. Falla (Oxford: Clarendon Press, 1978); p. 410: "Marx's basic principle is that all mediation between the individual and mankind will cease to exist. This applies to all constructions, rational or irrational, that interpose themselves between the individual and his fellows, such as nationality, the state, and law."

82. "Theses on Feuerbach," pp. 143, 145. In suggesting that the "Theses on Feuerbach" can apply to Spinoza as well as to Feuerbach, I follow the lead of the Soviet Marxist philosopher A. M. Deborin, who viewed Feuerbach as "a nineteenth-century neo-Spinozist." See George Kline's "Introduction" to Spinoza in Soviet Philosophy: A Series of Essays Selected and Translated (London: Routledge and Kegan Paul, 1952): 25.

83. See Kolakowski, Main Currents of Marxism, vol. 1, p. 127: Marx's “postulates... in ... the essay On the Jewish Question ... remain utopian (in the sense in which Marx later used this word) inasmuch as they simply oppose the actual state of man's dichotomy to an imaginary unity, described in very abstract terms."

84. "JQ," p. 46.

85. The Holy Family, in Marx and Engels, in Collected Works, vol. 4, p. 179.

86. Allen E. Buchanan, Marx and Justice: The Radical Critique of Liberalism (Totowa, NJ: Rowman and Littlefield, 1982); p. 64. See also pp. 163-75 for Buchanan's useful discussion of the reasons why the recognition of individual rights would be indispensable within a socialist order.

87. In this context it is interesting to consider one of Marx's earliest writings, his 1835 Gymnasium examination paper on "The Union of Believers with Christ According to John 15: 1-4, Showing its Basis and Essence, its Absolute Necessity, and its Effects." Although it is wrong to take juvenilia of this sort too seriously, the following remarkable coincidence is at least worthy of mention: "Union with Christ," Marx wrote, "causes us to keep His commandments by sacrificing ourselves for one another"; as a result of it, "we can for the first time love God, who previously appeared to us as an offended ruler, but who now appears as a forgiving father, as a kindly teacher" (Collected Works, vol. 1, p. 638). Thus Christianity as understood by the seventeen-year-old Marx connotes the abnegation of individual self-interest, and the disappearance of "offended ruler[s]"- 
precisely the characteristics that recur in the young Marx's discussion eight years later of "human emancipation."

88. To say this is not, however, to acknowledge the accuracy of the young Marx's contention that the inhabitant of liberal society is necessarily "an individual separated from the community, withdrawn into himself, wholly preoccupied with his private interest and acting in accordance with his private caprice" ("JQ," p. 43). For there is clearly a continuum between the total unity that the young Marx foresaw as a characteristic of communist society and the total atomization that he denounced as a characteristic of liberal society. It this context, it is worth noting that the Biblical commonwealth not only retained the affections of its subjects through its appeal to their "self-interest"; it also "inspire[d] the most ardent patriotism in [their] hearts" ( $T$ - $P$, chap. 17, pp. 230, 228). As Spinoza was well aware, there are certainly arguments to be made against communal solidarity on the basis of the sort of national, religious, or ethnic ties that characterized the Biblical Jewish commonwealth (see $T-P$, chap. 5, p. 76, chap. 17, p. 229); but it is by no means obviously the case that liberal societies mut be altogether atomistic, or altogether imcompatible with such solidarity. The young Marx wrote ("JQ,"p. 51) of "the chimerical nationality of the [nineteenth-century] Jew," whereas Spinoza contended that "the [exiled Jewish] nation" of his seventeenth-century contemporaries might be "preserve[d] . . forever," and might even "raise up [its] empire afresh" ( $T$ - $P$, chap. 3, p. 56). No proponent of Jewish nationalism, Spinoza nevertheless predicted the continuing power of nationality as a basis for communal solidarity. In light of recent history, both Jewish and non-Jewish, it is at least arguable that Spinoza's prediction has better stood the test of time than has the contrasting Marxist prediction of the inevitable demise of national solidarity within atomistic liberal societies.

Joel Schwartz is Assistant Professor of Political Science at the University of Michigan. He is the author of The Sexual Politics of Jean-Jacques Rousseau (University of Chicago Press, 1984). He is currently working on a study of Freud. 